The Permanent Tax Revolt 
This page intentionally left blank 


\section{The Permanent Tax Revolt}

HOW THE PROPERTY TAX TRANSFORMED AMERICAN POLITICS

Isaac William Martin 
Stanford University Press

Stanford, California

() 2008 by the Board of Trustees of the Leland Stanford Junior University. All rights reserved.

No part of this book may be reproduced or transmitted in any form or by any means, electronic or mechanical, including photocopying and recording, or in any information storage or retrieval system without the prior written permission of Stanford University Press.

Library of Congress Cataloging-in-Publication Data

Martin, Isaac William.

The permanent tax revolt : how the property tax transformed American politics / Isaac William Martin.

p. $\mathrm{cm}$.

Includes bibliographical references and index.

ISBN 978-0-8047-5870-3 (cloth : alk. paper)-ISBN 978-0-8047-5871-o (pbk. : alk. paper)

1. Property tax-United States. 2. Taxation-United States. 3. United States-Politics and government. I. Title.

$\mathrm{HJ}_{4120 . \mathrm{M}} 37 \quad 2008$

320.973-dc22

2007044494

Typeset by Westchester Book Group in 10/14 Minion

Part of Chapter 4 first appeared in Isaac Martin, "Does School Finance Litigation Cause Taxpayer Revolt? Serrano and Proposition 13," Law and Society Review 40 (3): 525-557, @ 2006

Law and Society Association, published by Blackwell Publishing. 
To Amaha 
This page intentionally left blank 